\title{
Paulo Leminski: sinais de vida e sobrevida
}

\author{
Celia Pedrosa
}

Para o Franklin

Perto do coração não tem palavra?

Ana Cristina César

Não sei parar na hora/ certa.

Cacaso

Sinais de vida foi o nome escolhido por Paulo Leminski, em 1978, para uma possível revista ou "IMPrevista de vulgarda", isto é, "de uma vanguarda vulgar", que divulgaria poemas definidos como "+ sinais de vida". Essa definição tem seu caráter dialético indicado e enfatizado pelo escritor mediante a combinação de quiasmo e recurso gráfico: "sinais DE VIDA de vida mas SINAIS". Segundo Leminski, ela atualizaria um motivo fornecido por opinião do poeta Décio Pignatari, que ele então pede emprestada para epígrafe da publicação: "talvez os signos sejam contra a vida"*. Esses dados, ainda que poucos, e inscritos no tex to curto e informal de uma das cartas dirigidas por Leminski a seu amigo e também poeta Régis Bonvicino, permitem vários desdobramentos. Através deles, pode-se reencenar, em alguns de seus aspectos, o diálogo entre a experiência pessoal do poeta e a cultura da virada dos anos 1970 e início dos anos 1980.

É nesse período que ele publica regularmente seus livros, do "romance-idéia" Catatau (1975) à coletânea de entrevistas e resenhas Paulo Leminski e ao tex to infanto-juvenil Guerra dentro da gente (1988), numa série que inclui ainda livros de poemas, biografias, ensaios e traduções - produção que se desenvolveu quase sempre concomitantemente à sua atividade como publicitário e letrista de música popular. Desse modo, Leminski se exercita numa diversidade de práticas cujos limites ele inclusive constantemente afirma ser necessário romper, avaliando a necessidade e a produtividade do híbrido, como na proposta de revista de vulgarda, de uma vanguarda vulgar. A esse propósito, Régis Bonvicino considera que: 
"(Bonvicino, Régis. "Nota à $2^{\mathrm{a}}$ edição". Em: Leminski, Paulo \& Bonvicino, Régis. Envie meu dicionário. Cartas e alguma crítica. Ob. cit.: 9).

" (Leminski, Paulo. En saios e anseios crípticos. Curitiba: Pólo Editorial do Paraná, 1997: 11) a importância da obra de Paulo Leminski reside principalmente no fato de ter sido ele um dos poucos, na segunda metade deste século, retomando Oswald de Andrade e Mário de Andrade, a trabalhar, de modo radical, com a idéia de dissolução e de limite. Entre prosa e poesia; entre estamentos da cultura, como erudito e popular; entre "áreas" de conhecimento, como história e filosofia; entre informação e comunicação; entre legível e ilegível etc.*

Escritas em 1999, na nota à segunda edição das cartas por ele trocadas com Leminski nesse período, essas palavras adquirem maior alcance, se lidas em relação com as que o próprio Leminski escreve para e a propósito de Régis em carta anterior, a ele dirigida, de 1980:

[seus poemas] são índices, pra mim, apontando para um grau/ momento de dissolução do magma poético tradicional, mais avançada essa dissolução que na minha própria poesia, ainda malassombrada por cadências/ritmos/formas psicografadas de outras eras...*

Através dessa relação, percebe-se que a prática de dissolução de limites entre diferentes espaços e níveis da vida cultural se associa também a uma prática de leitura e produção poética marcada por um interesse também plural, que supõe o convívio com diferentes tempos - de Petrônio a Samuel Beckett, cujas obras traduziu, de Bashô a Cruz e Sousa, cujas vidas biografou. Tanto em uma quanto em outra dessas práticas, o trabalho de produção e decifração de sinais de vida, de vida mas sinais, implica a desestabilização das próprias noções de vida e linguagem, poesia e cultura, pois, para Leminski, "é próprio da natureza do sentido" que "ele não existe nas coisas, tem que ser buscado, numa busca que é sua própria fundação”* Essa desestabilização e essa busca implicam, ainda, repensar o próprio significado da inserção em sua época, o próprio significado de sua "contemporaneidade" - "malassombrada” pela presença sobrevivente de "cadências/ritmos/formas psicografados de outras eras" e também, de certo modo, pela morte precoce que faz dele e de vários companheiros póstumos em relação ao seu próprio tempo.

Assim, o fim do século, a partir desses sinais, passa a relevar de uma intrincada tessitura de tempo, vida e linguagem que nos convida a nele tentar enxergar o sentido problemático da "historicidade irremediável e incorrigível”, "além de escolas 
correntes tendências”, que Leminski se atribui*, e que se esboça a contrapelo das formas mais convencionais de historicismo ${ }^{1}$. Desse momento, é bem emblemático o esboço de Sinais de vida como uma revista - publicação em série que, no entanto, supõe o imprevisto e o descontínuo, existente em grande escala então ${ }^{2}$; e que, inicialmente em seu caráter de iminência, e mais tarde como projeto abortado, presença feita de ausência, não deixa de produzir efeitos provocativos de significação, apontando possibilidades, lugares, valores atribuíveis à atividade de escritura. Não por acaso, segundo Leminski, esse projeto representaria "um gesto de vanguarda sígnica politicamente explícito" e "parte dos festejos comemorativos pela volta da greve da crise da história"*

Introduzindo e ao mesmo tempo já desestabilizando aí a idéia de comemoração, ao entronizar através dela como evento histórico exemplar justamente a crise da própria história, Leminski aponta para um modo diverso pelo qual esse gesto de vanguarda, enquanto iminência de algo ainda por vir, também se define a partir da relação com o passado. E esta é mobilizada, na passagem acima referida, através do procedimento de leitura e retorno a seu texto do texto e da figura de Décio Pignatari, um dos líderes do projeto concretista, lançado em 1958. Décio é definido por Leminski como um híbrido e impuro “osasquense operário bárbaro bizantino”, capaz de aplicar “um grande repertório nas coisas pequenas”* e pensar ao mesmo tempo, por exemplo, poesia e futebol. E ainda como "patriarca”, que ensina ao "discípulo dileto" que a relação com a tradição deve ser - conforme Leminski confirma tanto na moderna filosofia hegeliana, através do conceito de Aufhebung, quanto na milenar sabedoria budista, da qual recorda a metáfora da "transmissão da lâmpada" - simultaneamente de acolhimento e desconstrução: "É preciso acabar com o concretismo, e quem pode fazer isso são vocês...”* .
" (Leminski, Paulo \& Bon. vicino, Régis. Envie meu dicionário. Cartas e alguma crítica. Ob. cit.:153).

${ }^{1}$ Remetemos aqui, evidentemente, à reflexão de Walter Benjamin sobre a tarefa do historiador materialista e dialético em "Sobre o conceito de história" (Em: Benjamin, Walter. Obras escolhidas. São Paulo: Brasiliense, 1985). A ela retornaremos adiante, a propósito da oposição entre símbolo, signo e ícone, tal como proposta por Leminski.

${ }^{2} \mathrm{O}$ próprio Leminski sugere a produtividade da reflexão sobre a relação entre poesia e publicação serial, principalmente em revistas, ao dizer, humoristicamente, que "os maiores poetas (escritos) dos anos 70 não são gente. São revistas" (citado por Melo, Tarso. "Notas às cartas”. Em: Leminski, Paulo \& Bonvicino, Régis. Envie meu dicionário. Cartas e alguma crítica. Ob. cit: 177). 
(: 43, 45).

* (: 43).

* (: 111)

Desse modo, Décio ajuda o jovem poeta a definir-se também hibridamente como centauro, "último concretista e primeiro sei lá o quê", "metade decadentes alexandrinos bizantinos/ e metade bandeirantes pioneiros Marcopolos/ Simbad/ Livingstones/ David Crockets"*, reencenando assim a mistura de passado e porvir, ambos em aberto, fantasmáticos, na configuração de uma identidade presente: "já consegui ver a fímbria de algo/ q já não é mais concretismo/ embora o pressuponha e o tenha deglutido"*. Essa mistura, em sua relação com uma historicidade de crise, e em função mesmo da utilização da metáfora da transmissão da lâmpada, polemiza com a idéia de relação com a tradição como transmissão do bastão, tal como formulada por Antonio Candido em sua definição do sistema literário brasileiro ${ }^{3}$. Entre bastão e lâmpada, a diferença entre a afirmação do passado como presença e como estímulo a procurar algo ainda desconhecido - diferença que Leminski reconhece ainda nas palavras do mestre do hai-kai Bashô: "não siga as pegadas dos antigos,/ procure o que eles procuraram"*.

No período a que nos referimos, o processo de transmissão do bastão tinha mesmo que passar a ser pensado, positivamente ou negativamente, como em crise. O projeto concretista impusera a si como tarefa fundamental, ao longo dos anos 1960, a constituição de uma "tradição sincrônica", tecida na relação com mais diversos poetas, das também mais diversas inserções sociais e históricas. Enfatizam-se, então, como critérios de seleção, a consciência da linguagem e a capacidade de inovação, e são desconsiderados o vínculo de referencialidade e a identificação com uma brasilidade específica que, junto com a retórica sentimental, constituiriam a herança romântica até então hegemônica. Na década de 1970, essa demanda se enriquece ainda com a consciência, cada vez mais inalienável, da relação entre cultura erudita e cultura de massas - na qual, inclusive, através de linguagens como a da música tropicalista, a tensão entre tradição e experimentalismo, nacionalidade e globalização, é encenada de modo a incorporar e simultaneamente desestabilizar a herança concretista. A poesia marginal se inscreve ainda nesse espaço para, em função da oposição

${ }^{3}$ De modo bastante polêmico, Haroldo de Campos discute o conceito de literatura brasileira e a história da constituição de sua tradição, apresentados por Antonio Candido em Formação da literatura brasileira (São Paulo: Martins, 1959), em O seqüestro do barroco (Salvador: Fundação Casa de Jorge Amado, 1989). 
entre vida e biblioteca, encenar uma forma alternativa de associar poesia, coloquialismo e cotidiano, herdada do modernismo, em que a ideologia do desbunde substituía a consciência nacional e o espontaneísmo, o investimento na experimentação formal ${ }^{4}$.

Imerso nesse contexto, o discurso leminskiano, por sua vez, além de abrir-se a sua compreensão, nele se motiva para, inquietamente, impor-lhe nova desestabilização. E isso, à medida que, por seu empenho na dissolução de limites, tenta evitar as dicotomias - entre construtivismo e afetividade, entre linguagem e vida, entre experimentalismo e experiência - que serviam então, como ainda servem, de balizas para o pensamento crítico. Vemos, assim, como, por meio de sua leitura de Décio Pignatari, bem como de seu próprio auto-reconhecimento como concretista, a origem concreta retorna com um valor diferenciado, mobilizado pela própria posterioridade que ajudou a deflagrar:

Minhas ligações com o movimento concreto são as mais freudianas que se possa imaginar. [...] A coisa concreta está de tal forma incorporada à minha sensibilidade que costumo dizer que sou mais concreto que eles: eles não começaram concretos, eu comecei. $^{*}$

Bem como afirma Walter Benjamin, desse modo se encena que: A origem é um turbilhão no rio do devir, e ela arrasta em seu ritmo a matéria do que está em vias de aparecer. [...] Ela pede para ser reconhecida, de um lado, como uma restauração, uma restituição, de outro lado, como algo que por isso mesmo é inacabado, sempre aberto. […] Em conseqüência, a origem não emerge dos fatos constatados, mas diz respeito a sua pré e pós-história.*

Mobilizado nesse devir, o concretismo deixa de ser índice apenas de rigor construtivo, para indicar uma produtiva tensão entre linguagem e vida, entre tradição e experimentação, entre necessidade de inovar e de comunicar. Por isso, Décio, bárbaro bizantino moderno, pode ser a referência fundadora de uma vanguarda imprevista e vulgar, que tenta articular esses pólos em tensão, ampliando seu alcance. Explicitando essa vontade de

* Silviano Santiago tem papel fundamental no esforço de identificação e sistematização crítica dessas transformações. Nesse sentido, seu primeiro livro de ensaios, Uma literatura nos trópicos (São Paulo: Perspectiva, 1978) foi e é ainda importante referência.
"(: 208-9).

"(Benjamin, Walter. Origem do drama barroco alemão. São Paulo: Brasiliense, 1984: 67.68). 
" (Leminski, Paulo \& Bon. vicino, Régis. Envie meu dicionário. Cartas e alguma crítica. Ob. cit.:142)

"(: 78).

"(: 141).

"(: 73).

articulação através de uma forma de discurso que, em si mesma, já encena o hibridismo entre signos de paradigmas poéticos em princípio pensados como opostos, o salão e o salooni", Leminski afirma que "é preciso ser moleque/ relaxado com o rigor", pois "ou minha consciência de linguagem é útil ao ar livre e à luz do dia.... ou então wait a minute, something is wrong" ${ }^{1 * 5}$.

Nesse processo, Leminski, ao questionar, por exemplo, a célebre postulação concretista que "dá por encerrado o ciclo histórico do verso”, está atualizando-a a partir de experiências posteriores por sua vez bem diversas. Por um lado, a intensificação da demanda por pluralidade, na esteira da crítica política a toda forma de fascismo que sacode a cultura no Ocidente após os acontecimentos de maio de 1968, privilegiando a recusa ao autoritarismo, inclusive e principalmente o vanguardista, em detrimento de polarizações ideológicas entre esquerda e direita, capitalismo e socialismo: "entre o verso e o universo/ o subverso versus o reverso/ tem lugar para todo mundo"*. Por outro, o reconhecimento da necessidade de a produção artística pautar-se também pelo padrão de expectativa de um público maior, ampliar sua possibilidade de circulação, numa imprevista mistura de estética, política socialista e cultura pop, como quando aconselha Régis Bonvicino: "v. tem que socializar teu discurso, ser mais político, dialogar, conversar, inter-essar! Poesia de vanguarda não é orquídea... não pose para os campos do futuro te flagrarem em atitude de 'radicalismo intransigente!' besides, não combina com teu jeans...”*.

O mesmo ocorre em relação ao lema concretista da inovação, pois contra o "make it new" poundiano se impõe a consciência de que "o esplêndido isolamento 'radical' dos poetas inventores numa nação de medíocres poetas sociais é apenas um dos papéis roles possíveis... e vai ficar cada vez mais furadinho"*. Em conseqüência, afirma que "precisamos tirar a poesia da vertigem/miragem do novo, novo, mais novo, mais, mais..." criticado sem dúvida em função de sua crescente e insofismável ligação com o consumismo capitalista. Ao apontar essa ligação,

\footnotetext{
${ }^{5}$ Embora de forma ligeira, é importante registrar que uma das formas de figurar esse hibridismo é justo através do convívio de línguas, no caso o português e o inglês. Desse modo, Leminski dissolve, junto com a fronteira entre línguas, a fronteira entre o erudito e o popular, o nacional e o estrangeiro, por intermédio de uma referência provocantemente ambígua, já que o inglês tanto é a língua hegemônica da comunicação de massa globalizada quanto é a língua do poeta-guia fundamental do empenho de rigor e inovação concretistas, Erza Pound.
} 
desestabilizando mitos estéticos e políticos associados à idéia de originalidade e transformação radical da arte e da vida coletiva, provoca então reações bastante negativas ${ }^{6}$ :

fiz uma palestra/ debate/ proposta minha/ na arquitetura daqui sobre o tema O BELO VERSUS O NOVO/ no qual desenvolvi a idéia seguinte/ isso que se chama arte moderna/ deslocou o centro da idéia de BELO para a idéia de NOVO/ q eu disse ser própria de sociedades industriais em adiantado estado de consumismo/ capitalistas ou socialistas/ o pau que quebrou vou te contar."

Mas esse diálogo entre a origem concreta e a contemporaneidade ganha novos matizes através da rememoração que as remete também a sua pré-história - segundo as palavras de Benjamin acima referidas. Esta se instaura no discurso de Leminski através da referência à poesia e à crítica de Mallarmé. Dele relembra, por exemplo, a dissociação entre inovação e contemporaneidade: "Difícil descobrir o novo nas coisas recentes/ elas tendem a ser contemporâneas/ e como dizia papa Mallarmé, des contemporains ne savent pas lire"*.

Esse Mallarmé que aí retorna, aproximando dois distintos fins de século, é o mesmo que aparece já numa leitura do concretista Haroldo de Campos datada de 1958. Nela é enfocada a articulação entre a ordem e o acaso no poema "Un coup de dées", evidenciando o talvez como um dos signos centrais de seu discurso: "A procura do absoluto, fadada por definição à falência, entrevê um êxito possível na conquista relativa sancionada por um talvez: a obra-constelação, evento humano, experiência viva e vivificante"*. Conforme percebe Leminski, nessa mesma direção, "sem abdicar dos rigores da linguagem, precisamos meter paixão em nossas constelações"*.

A presença do talvez é então um dos signos da relação não dicotômica entre vida e linguagem, que Leminski identifica como lição a ser apreendida em Décio, "na vida que ele é e faz"*. É essa mesma relação que o leva a valorizar o texto do autor japonês Mishima, por ser "todo perfumado de parece-me", dando-lhe a impressão de que "nada mais me restava senão
"(: 35).

"(: 36).

" (Cf. "Lance de olhos so bre um lance de dados". Em: Campos, Augusto de; Campos, Haroldo de \& Pignatari, Décio. Mallarmé. São Paulo: Perspectiva, 1991: 190)

" (Leminski, Paulo \& Bon vicino, Régis. Envie meu dicionário. Cartas e alguma crítica. Ob. cit.:45).

"(: 89).

\footnotetext{
${ }^{6}$ Essa desmistificação, associada à valorização do caráter revolucionário, mobilizador, da ordem capitalista burguesa e à explicitação das relações entre essa ordem e a arte moderna, é sistematizada por Marshall Berman em seu Tudo que é sólido desmancha no ar (São Paulo: Companhia das Letras, 1987).
} 
"(Leminski, Paulo. Ensaios e anseios crípticos. Ob. cit.: 36).

" (Campos, Augusto de; Campos, Haroldo de \& Pignatari, Décio. Mallarmé. Ob. cit.: 120)

"(Leminski, Paulo. Ensaios e anseios crípticos. Ob. cit.: 14).

" (Leminski, Paulo \& Bon vicino, Régis. Envie meu dicionário. Cartas e alguma crítica. Ob. cit.: 35 )

"(: 97)

"(145).

"(: 47).

"(: 100). entregar-me à necessidade de vir a pensar que, formulações extremamente mediatizadas, cautelosas, especulares, refrações como que gasosas, muito mais complexas do que a brusquidão totalitária do [...] estilo ocidental de emitir o conceito, lapidar concisão herdada da dura lex sed lex do latim idioma de legisladores e administradores, nossa mãe e superego"**.

Essa presença pode ser considerada homóloga a outra marca do texto leminskiano, o uso constante de reticências, associável também à flexibilização da ordem sintática é à suspensão da continuidade lógico-temporal que esta supõe. Retornando ainda uma vez a Mallarmé, tal como lido por Haroldo de Campos, agora em texto de 1972, aprendemos que a suspensão é um efeito discursivo produzido pelo trabalho na frase, no verso, e não por sua abolição:

Mallarmé é um sintaxier exímio, um perito em elipses e arabescos, um reversor de ordens: "je suis profondément et scrupuleusement sintaxier”. Hamlet da sintaxe, suspendendo o discurso num espaço de rupturas, por parênteses e cláusulas hipotéticas, avançando e recuando, por gerúndios e ablativos absolutos, por uma fioritura de apostos, até um vértice/vórtice de dúvida indecidível...*7.

Em todas essas marcas, reafirma-se a preocupação de Leminski com o que ele chama de dialética - em função com certeza de forte leitura hegeliana e marxista -, mas que se concretiza, na verdade, mais como oscilação, hesitação, in-definição. Ele mesmo se declara muitas vezes dividido entre tendências irreconciliáveis à inovação e à comunicação, à erudição livresca e à abertura ao popular. E ora se diverte “em pensar que, em vários momentos, estou brigando comigo mesmo"*, ora se angustia tentando conduzir "com alguma elegância meu destino de médico e monstro", em busca da impossível síntese "zenmarxistaconcretista” que pacificaria a ele e a sua geração*. Por isso, é capaz de confessar gostar de se sentir "na corrente sanguínea/ do mercado e dos meios de massa..." e, ao mesmo tempo, invocar o espírito bolchevique e trotskista para, em tom de manifesto, reivindicar "todo o poder à poesia!"*, não sem antes considerar que mudar a vida é que é o grande poema, e a utopia socialista o único objetivo verdadeiro da produção poética.*

${ }^{7}$ A propósito de uma "filosofia da pontuação", é interessante a reflexão de Gilles Deleuze em Critique et clinique (Paris: Minuit, 1993). A relação feita entre suspensão sintática e temporal, e a imagem de Hamlet será comentada adiante. 
Por outro lado, isso não o impede de valorizar em Trotski justamente a inteligência pluralista, aberta, hesitante*, que o torna capaz de passar da crítica stalinista à autonomia da arte à expectativa de um tempo em que "a vida enriquecerá em proporções tais que se modelará, inteiramente, pela arte”**. Essa inteligência, por seu turno, Leminski a reconhece tão produtiva na ação política quanto na intensa produção bibliográfica, cujo estilo fundia palavras de fogo e ordem, entusiasmo e lógica* Com o líder da revolução russa, Leminski desenvolve também uma relação em que a admiração se associa à irreverência, expressa na imagem em que em um e outro se dissolvem limites entre força política, misticismo e super-heroísmo da comunicação de massa: "viver é duro, mas é bom. (quando fraquejo, me lembro de Trotsky, meu exu, e viro hulk de novo"** Ao mesmo tempo, reconhece que essa força pode ser sua fraqueza, pois o caráter errante, pluralista, por isso vigoroso, de sua inteligência também o induz ao erro e à morte precoce, signos da crise da própria experiência do socialismo**

Associada à experiência da história e da linguagem como crise, a hesitação seria também, segundo Régis Bonvicino, uma marca de outros poetas daquela época, como Torquato Neto e Ana Cristina César* . No verso de Ana que escolhemos para epígrafe, ela se situa no espaço da dúvida e do impasse entre a experiência do corpo e da linguagem. Também em Cacaso essa hesitação se apresenta, como experiência de estar "na corda bamba” - nome de uma coleção de poesia que não chegou a acontecer e, mais tarde, tornou-se título de um poema e de um livro seus ${ }^{8}$. Em ambos, como também em Torquato, e no próprio Leminski, além disso, o distanciamento crítico em relação à sua época é encenado, ironicamente, pela própria morte, também precoce, que parece ser mais um desestabilizador de grandes certezas, seja na relação espontânea entre linguagem e vida em liberdade, seja na experimentação formal construtiva e inovadora: a vida, como a linguagem, não se pode make it new por decreto*.

Afinal, esse é um tempo caracterizado justamente pelo fato de que, segundo Leminski, "talvez não haja mais tempo/

${ }^{8}$ A esse respeito, leia-se Antonio Carlos de Brito. "Sinal dos tempos e dos espaços”. Em: Não quero prosa (Rio de Janeiro/Campinas: EdUFRJ/EdUNICAMP, 1997). O poema está na coletânea Lero-lero (São Paulo/Rio de Janeiro: Cosac \& Naify/ 7 Letras, 2002).
" (Leminski, Paulo. Vida. Biografias de Cruz e Sousa, Bashô, Jesus e Trotski. Por to Alegre: Sulina, 1990: 320).

* (: 333)

* (: 227)

" (Leminski, Paulo \& Bonvicino, Régis. Envie meu dicionário. Cartas e alguma crítica. Ob. cit.: 131).

"(Leminski, Paulo. Vida. Ob. cit: 322 ).

"(Bonvicino, Régis. "Nota à $2^{\mathrm{a}}$ edição". Ob. cit.: 235).

"(:114) 
" (Leminski, Paulo \& Bonvicino, Régis. Envie meu dicionário. Cartas e alguma crítica. Ob. cit.: 50).

* (: 49).

"(: 210).

(: 110).

" (Leminski, Paulo. Ensaios e anseios crípticos. Ob. cit.: 59).

"(: 59).

"(: 62, grifo nosso). para grandes e claros GESTOS INAUGURAIS/ como a poesia concreta foi/ a antropofagia foi/ a tropicália foi/ agora é tudo assim/ ninguém sabe/ as certezas evaporaram*. A partir dessa incerteza, além de perceber sua oscilação entre extremos irreconciliáveis e sonhar com uma impossível síntese, ele critica todas as formas de sectarismo que vinham tentando hegemonizar nossa vida cultural nas últimas décadas, e que por isso mesmo fazem parte de sua própria identidade conflitante. Assim faz em relação ao que chama de "esquerdofrenia", avaliando que a necessidade de pensar a relação entre poesia e história deva ser feita pela associação de Know how, don't know how e whatever it is ${ }^{*}$, e caracterizando os poetas agrupados em torno do "Violões de Rua" como "românticos bobalhões"*. Por outro lado, também critica o vanguardismo que esquece a história, e em nome de um culto ao novo de cunho "esteticista" e "stalinista", não se vexa de invocar um escritor fascista como Erza Pound e, pior ainda, colocá-lo ao lado do revolucionário Maiakovski*. Lá como aqui, Leminski identifica o mesmo radicalismo judicativo, a mesma pretensão arrogante a mudar completamente o mundo e a poesia*.

Em função disso, valoriza os poetas marginais por quererem resgatar a poesia como pura alegria de existir; ao contrário das outras, esta "não queria nada. Só queria ser. A palavra para isso era 'curtição', a pura fruição da experiência imediata, sem maiores pretensões"*. Mas ao mesmo tempo considera que a literatura não pode se esgotar nessa fruição, apenas começar por aí, já que “cedo, lendo, a gente descobre, lá fora existe, não apenas um mundo mas também uma literatura, um universo feito de palavras, frases perfeitas, enredos inesquecíveis, versos definitivos, 'performances' verbais tão vivas quanto a própria vida, e que sobrevivem à própria morte do autor"**.

Através desse conjunto de avaliações, que esboçam um lugar hesitante para a reflexão crítica e para a prática poética, Leminski intervém em seu contexto e momento pelo empenho em esvaziá-los de uma evidência cerrada e plena. A relação entre vida e linguagem encena uma historicidade de crise - dúvidas, lacunas, ausências. O tempo passa a ser vivido como limiar, o

${ }^{9}$ É interessante notar aí o uso da noção de performance associada à palavra escrita e à sua capacidade de permanecer - uso que entra em curto-circuito com a tendência hoje dominante de invocar a performance em sua relação com a oralidade, a efemeridade e a facilidade de circulação, em oposição à da literatura escrita. 
espaço como corda bamba, a linguagem como experiência que diz respeito à distância, à presença enquanto sobrevida. O uso dessa noção, associada aí à vida na e da linguagem, permite retornar à formulação inicial de Décio Pignatari - "talvez os signos sejam contra a vida”, que Leminski recupera e transtorna, desdobrando o conceito de signo em símbolo, índex e ícone-, a partir da leitura concretista de Charles Peirce, para então concluir: "a vida não é contra os ícones nem contra os índices/ vida é ícone (dança, sexo, guerra)/ e índex (caminhos, direções, roteiros)/ é o símbolo que é contra a vida"*

Essa formulação pode ser bem compreendida se acompanhamos, por exemplo, o processo pelo qual a leitura de Leminski, de novo fundindo vida e linguagem, dota de sobrevida a figura e o texto de Cruz e Sousa, ao escrever uma biografia cujo eixo é justamente uma releitura do significado do símbolo e do Simbolismo. Segundo ele, os simbolistas foram os primeiros modernos, em sua descoberta do caráter concreto, icônico, da experiência sígnica, direcionada por eles para a tensão sempre não resolvida entre pensamento, palavra e imagem. Nessa tensão, a linguagem se constitui como lugar de afirmação de um resto, de uma mais-valia, de uma abertura à indeterminação que implica intersemioticidade, rompimento de fronteiras dos sentidos e do sentido*.

A necessidade de "programar essa indeterminação” enrijece a experiência sígnica e a torna refém do símbolo - cristalização idealizada da relação entre palavra e pensamento, que Walter Benjamin identificara na arte clássica, à qual contrapunha a mobilidade, a fragmentação, a abertura verbal e imagética da alegoria barroca* ${ }^{*}$ Esse mesmo processo de enrijecimento simbólico é analisado por Jacques Ranciére como característico de grande parte da produção poética do século XIX, pautada na institucionalização de semelhanças e, assim, servindo a um conceito de História que, na verdade, implica sua mesma negação. Segundo ele, essa negação se dá através do esvaziamento da materialidade de palavras e coisas, ocultando pela semelhança o que as tornaria sempre irredutíveis umas às outras:

O século XIX $[\ldots]$ pretende ser o século da História, mas na verdade é antes o século anti-histórico, o século "búdico". O "progresso" inventado por ele é a recusa da historicidade e da morte que suporta o sentido daquela. Esse fantasma de história não passa do resumo de suas viagens para todos os lados para tapar, com o visgo de seus tentáculos, todos os espaços vazios do sentido, do tempo e da morte.*
"(: 124)

" (Leminski, Paulo. Vida. Ob. cit: 50.4).

"(Benjamin, Walter. Origem do drama barroco alemão. Ob. cit.).

" (Rancière, Jacques. Polí ticas da escrita. São Paulo: Editora 34, 1995: 124). 
* (: 129).

" (Leminski, Paulo \& Bonvicino, Régis. Envie meu dicionário. Cartas e alguma crítica. Ob. cit.: 83 ).

"(: 150).

"(: 158)

* (: 48).

* (: 47).
Lembrando outro poeta, Rilke, para quem "só há espaço feliz quando é filho da separação", Rancière considera que o poder poético decorre sempre de uma vivência do exílio, do aprendizado da separação e da despedida, que permite o acontecimento do encontro livre e aleatório de palavras e coisas*. A experiência sígnica empreendida por Leminski se organiza justamente como sobrevida, a partir da consciência de que "as coisas que você faz/ você faz passando/ e para passar"; também, em conseqüência, da conclusão de que "é em signos que se fica, o resto é moldura" " - reflexões suscitadas pela morte do filho Miguel, mas extensíveis à toda relação entre vida, sobrevida e linguagem. Questiona, assim, a associação entre vida, presente e presença, plenitude e experiência empírica, valorizando, ao contrário, a linguagem como lugar de sua própria experiência vital mais intensa - "vivo para fazer poesia"*

Nesta, além disso, a possibilidade de permanência é feita de lacunas, hipóteses, sentidos ainda em suspenso, inclusive à medida que essa sobrevida implica constante desestabilização dos limites espaciotemporais em que se circunscreveriam a origem e a identidade autorais. Enquanto sinais de vida, então, os signos que constituem toda linguagem se organizam segundo um duplo movimento de permanência e transformação, fora de toda possibilidade de pacificação, sendo, por isso, associados por Leminski à idéia de guerrilha. Fundamental à experiência política e cultural de sua geração, essa estratégia de luta se identifica com a linguagem porque, segundo ele, nesta "as batalhas nunca são decisivas/ as vitórias são confusas/ cf. Peirce/ signos geram signos por cissiparidade por hibridismo por mutação/ prolíficos/ promíscuos/ fecundos como os insetos"*.

Por meio da idéia de guerrilha, Leminski associa a atividade de escritura à estratégia política de inserção no terreno inimigo para nele se alimentar e, ao mesmo tempo, minar sua força* Essa definição também é atribuída a Leminski por Waly Salomão, outro poeta que, nascido desse contexto de crise, faz da linguagem um espaço de crítica à dicotomia entre arte e vida. Mas embora associe a atitude guerrilheira à recusa da erudição livresca e à inserção do artista no mundo da contracultura e da cultura de mercado, também critica, por outro lado, a crença espontaneísta da geração marginal, rótulo no interior do qual confessa nunca ter se sentido confortável. A relação entre arte e vida se configura, em sua poesia protéica, pela encenação constante da máscara, da recusa da identidade 
a si mesmo, solicitando para isso o eco das mais diferentes formas de linguagem ${ }^{10}$.

É com certeza por esse caráter vital e combativo de guerrilha - estratégia protéica, plural, hesitante - que o trabalho com a linguagem se torna então para Leminski o principal e praticamente único assunto de uma escritura em princípio também determinada pelo vínculo imediato com a ação e a sensação cotidianas, as cartas. Numa delas, inclusive confessa que "nunca fui muito bom nesse negócio chamado vida/ mas o tempo/ entre um poema e outro/ me ensinou umas coisinhas"* . Lugar promíscuo, de dissolução de limites, prolífico, de desdobramento e iminência de sentido, a linguagem significa errância e, no duplo sentido que esse conceito comporta, também significa o erro. Enquanto sobrevida, a guerrilha dos signos implica, principalmente, o erro que, em relação à vida e à presença plenas, a morte representa. É por isso que, a propósito da história da poesia, Leminski declara:

O Livro dos mortos é o mais antigo texto poético conhecido. Muito significativo que a leitura já comece sob o signo da morte. Da múmia. De Osíris. Todo texto é, desde o princípio, um Osíris, um morto, destinado a ressuscitar à luz do ritual de sucessivas leituras, traduções e interpretações. ${ }^{*}$

A relação intrínseca entre erro, errância e uma prática móvel e vital do pensamento e da existência são abordador por Michel Foucault em um texto não por acaso escrito ao sabor das motivações da virada dos anos 1970 para os 1980, "A vida: a experiência e a ciência” ["La vie: l'expérience et la science" "]* Segundo Giorgio Agamben, esse tex to se configura como um gesto que, "arrancando o sujeito do terreno do Cogito e da consciência, o arraiga no da vida, mas de uma vida que, enquanto essencialmente errar, vai além das vivências e da intencionalidade da fenomenologia”* . Em tal experiência, a vida, antes pensada por Foucault como presença garantida por um “conjunto das funções que resistem à morte”, passa a incluir o "erro” da ausência e da morte. A morte é, assim, signo de uma forma de produtividade feita de suspensão e não de continui-

${ }^{10}$ Para uma compreensão do lugar de Waly Salomão na vida cultural brasileira e de seu diálogo com Paulo Leminski, é fundamental a leitura de Antônio Cícero. "A falange de máscaras de Waly Salomão". Em: Finalidades sem fim. São Paulo: Companhia das Letras, 2005.
* (: 84).

"(Leminski, Paulo. Ensaios e anseios crípticos. Ob. cit.: 29).

\footnotetext{
(Em: Foucault, Michel. Dits et écrits. Paris: Galli mard, 1994).

" (Agamben, Giorgio. "A imanência absoluta". Em: Alliez, Eric. Gilles Deleuze: uma vida filosófica. São Paulo: Editora 34, 2000).
} 
(Cf. Benjamin, Walter. "Experiência e pobreza" e "O narrador". Em: Obras escolhidas. Ob. cit.).

" (Leminski, Paulo. Vida. Ob. cit: 211).

"(: 66). dade, de ausência e não de presença, de interrogação e não de certezas escatológicas. A morte precoce fragiliza os conceitos de início e fim, põe em questão o próprio sentido da vida, na verdade repõe a relação entre vida, experiência e sentido, numa época em que se intensificariam os fatores responsáveis pela destruição da experiência, tal como identificada por Benjamin como característica da vida moderna*.

É significativo a esse respeito que a morte enquanto experiência vital seja explicitamente abordada por Leminski em seu já referido ensaio sobre Mishima, escritor no qual valorizou, como vimos, a vitalidade do discurso hesitante. Ou que sua biografia de Trotski seja fundada na relação com a história russa, tal como figurada no romance Os irmãos Karamazov, de Dostoievski. Além de permitir a Leminski fazer a associação entre processo revolucionário e parricídio, esse livro tem como epígrafe justo o versículo em que São João lembra que “Em verdade, em verdade vos digo que se o grão de trigo que cai na terra não morrer, fica infecundo: mas se morrer, produz muito fruto”. A morte precoce é ainda um dado significativo das figuras cuja biografia escolhe escrever - Trotski, Jesus, Cruz e Sousa, e Bashô - emblemas de uma vitalidade discursiva e política que não cessa de recomeçar. De Jesus, que atualiza em híbrido de poeta e revolucionário, diz, por exemplo, ser "um signo de leitura infinita”; de Cruz e Sousa, que pela musicalidade simbolista de seus versos e pelo peso da herança africana é associado a um compositor norte-americano de blues, lembra ao leitor que "Você, agora, sabe. Você, eu sou Cruz e Sousa"*

Como afirmamos, sua própria morte, também precoce, parece inclusive ter sido insistentemente buscada, como parte mesmo da intensidade de sua forma de experiência vital. Precoces são também as mortes que marcam sua vida familiar, como a do irmão, que se suicida, e a do filho Miguel, de câncer, com apenas dez anos. Precoces são ainda, lembremos, as mortes que marcam fortemente a vida literária e cultural desse período, como as de Torquato Neto, Cacaso e Ana Cristina César. A respeito das mortes desses poetas, e do trabalho póstumo de organizar o material escrito deixado por eles, o também poeta e crítico Julio Castañon Guimarães fez interessante observação:

Estas cartas deixadas por Leminski vêm a ser como que um embaralhador de tempos, criando superposições e hiatos, na medida em que escapam a um andamento de que se podia ter uma expectativa mínima. A morte prematura de seu remetente as tornou 
póstumas antes do tempo. E ao lado de Leminski, infelizmente, se contam nomes como Torquato Neto, Ana Cristina César, Cacaso, retirados, fora do tempo da seqüência de produção de sua geração. Assistimos então ao trabalho de recolha de esparsos e inéditos póstumos de uma geração que ainda está em plena atividade.*

Em “Sobrevida”, introdução que escreve, em 1990, para Vida, a coletânea póstuma das biografias escritas por Lemiski, publicadas separadamente, de 1983 a 1986, pela editora Brasiliense, a poeta Alice Ruiz, sua companheira durante vinte anos, lembra que Leminski, "a quem não interessava nada que não contivesse idéias e poesia, viveu nessa vida como um exilado. Como alguém que está fora do seu verdadeiro habitat. E precisa reinventar, através de signos, símbolos, sonhos, palavras, um simulacro mais próximo do seu conceito de vida"*. Por isso, através dos inúmeros e dispersos textos que escreveu, ela considera então que "ele soube, a exemplo de seus biografados, sobreviver à sua própria vida. Vida é uma prova viva disso”**

Sobrevivendo a si mesmo, através de poemas, cartas, ensaios e biografias, Leminski traz até nós um testemunho de seu tempo que, na fusão de linguagem, vida e temporalidade, transcende à evidência e ao mecanicismo das analogias. Feito de ausência, exílio, fim e/ou início prematuros, hiatos, embaralhamento de fronteiras espaciais e temporais, esse testemunho o torna desconjuntado, "out of joint", como diz de seu tempo o espectro que assombra Hamlet. É ele quem Jacques Derrida invoca para nos dizer do papel que os espectros, vindos do passado, exercem sobre o presente, juntando vida e morte numa "sobrevida cuja possibilidade vem desajuntar ou desajustar a identidade a si do presente vivo"*. É esse mesmo espectro hamletiano que Mallarmé invoca em seu poema e que Haroldo de Campos, na passagem já referida anteriormente, considera signo da capacidade de transtornar a linearidade sintática e histórica, fazendo do sentido dúvida e iminência.

E nessa associação entre transtorno de limites, embaralhamento de tempos e espaços, a idéia de exílio, associada aqui também à de vida, morte precoce e sobrevida, motiva a convocação de novo espectro - aliás, segundo Derrida, o espectro é propriamente o mais de um* ${ }^{*}$ Assim, a relação entre Leminski, seu tempo e sua origem solicita a figura de outro poeta francês do fim do século, convocada pelo mesmo Haroldo em 1983, ano da publicação da coletânea de poemas Caprichos e relaxos. Aí, num
" Guimarães, Julio Cas. tañon. "Cartas, interse. ções". Em: Leminski, Paulo \& Bonvicino, Régis. Envie meu dicionário. Cartas e al guma crítica. Ob. cit: 11).

"(Ruiz, Alice. "Sobrevida". Em: Leminski, Paulo. Vida Ob. cit.: 9).

"(: 10).

" (Derrida, Jacques. Es. pectros de Marx. Rio de Janeiro: Relume-Dumará, 1994: 11)

"(: 10). 
(Campos, Augusto de; Campos, Haroldo de \& Pignatari, Décio. Mallarmé. São Paulo: Perspectiva, 1991: 7). texto em forma de prólogo, ele relembra a aparição de Leminski no cenário da poesia brasileira, mais precisamente na semana nacional de Poesia de Vanguarda, realizada em 1963 em Belo Horizonte. Segundo Haroldo, ele surge então inesperadamente, como um "Rimbaud curitibano", "lampiro-mais-que-vampiro faiscante de vida e poesia”, para se transformar mais tarde em chuva que "vem chovendo no endomingado piquenique sobre a erva em que se converteu a neoacadêmica poesia brasileira de hoje, dividida entre institucionalizadas marginalidades plácidas e escoteiros orfeônicos, de medalhinha e braçadeiras"**.

Nessa avaliação de 1983, Haroldo com certeza leva em conta, naquele Leminski de vinte anos antes, sua juventude e irreverência, sua chegada imprevista, sem convite, dizem que literalmente de carona, de um "exílio" curitibano fora do eixo Rio de Janeiro - São Paulo - Belo Horizonte. Ao mesmo tempo, superpõe a esses dados outros, somente conhecidos bem $a$ posteriori, e que lhe permitem associar Leminski e Rimbaud por meio de um semelhante e auto-destrutivo envolvimento com álcool e/ou drogas que o primeiro só desenvolverá mais tarde ${ }^{11}$. A esses aspectos, vêm se juntar, contraditoriamente, aqueles que na verdade desconstroem a mitologia contracultural que fez de Rimbaud um símbolo da oposição entre vida e poesia, pois o Rimbaud curitibano de então, na verdade, ia ao encontro da poesia, da poesia de vanguarda, da vanguarda concretista conhecida na época por sua postulação intelectualista, contra o espontaneísmo sentimental e o realismo característicos, segundo ela, de uma dicção literária empobrecida.

É esse caráter plurívoco do espectro rimbaudiano que certamente motivou Régis Bonvicino na escolha do título dado à segunda edição da coletânea de cartas a ele enviada por Leminski: Envie meu dicionário. Como informa na nota a essa edição, teria se inspirado num verso traduzido por ele de Canções herméticas, do poeta americano Michael Palmer, que, por sua vez, lhe havia declarado tê-lo tirado também de uma carta, não de Leminski, nesse caso, mas do poeta francês, que a enviara à família de seu auto-exílio africano. A leitura dessa

${ }^{11}$ Mario Cámara faz uma interessante leitura dessa relação como procedimento anacrônico de fundação de uma origem, contrapondo a abordagem de Haroldo de Campos àquela feita por Caetano Veloso na contracapa do mesmo livro de poemas de Leminski. Cf. Mario Cámara. "Mistura, pororoca y fantología” (Gragoatá: Revista do Programa de Pós-Graduação em Letras da Universidade Federal Fluminense, n. 17. Niterói, 2005). 
correspondência comprova que o pedido de Rimbaud, várias vezes reiterado, de envio de dicionários técnicos ou de língua árabe e africana, era motivado pela necessidade vital de se comunicar e de trabalhar no que escolhera como alternativa à poesia. Régis não leva em conta esse dado mais pragmático, mas de todo modo afirma que a preocupação com o dicionário resgata para sua coletânea a idéia de que "nada há de mais cotidiano e vital, para um poeta, do que as palavras!"* - idéia que Leminski defenderia também uma vez que, segundo seu correspondente e leitor assíduo, “a partir dos anos 80, afirmava insistentemente, em entrevistas e peças de ensaio, que sua única e favorita leitura eram os dicionários!"*12.

Essa referência à correspondência rimbaudiana repõe a questão da relação entre vida e linguagem a partir da referência ao pensamento de Georges Bataille, pois, em 1929, no segundo número da revista Documents, ele introduz justamente uma seção intitulada "Dictionnaire critique", que, ao longo dos números seguintes, enumera verbetes tão díspares quanto trabalho, esteta, boca, museu, anjo, arquitetura, rouxinol, olho, absoluto, materialismo, poeira, camelo e chaminé, entre outros. Segundo Martin Jay, para Bataille, "os dicionários realmente começam qundo deixar de dar significados fixos às palavras e, em vez disso, meramente sugerem sua tarefa de final aberto"*.

Associando assim as palavras dicionarizadas a um valor performático-associável ao que já vimos ser atribuído por Leminski ao trabalho com a palavra -, em que a função de nomeação e classificação fixa é substituída pela enumeração de possibilidades e, portanto, pela capacidade de desestabilizar e criticar, Jay remete a reflexão batailleana à tensão entre a forma e o informe, entre a representação e sua impossibilidade, entre a organização racional do pensamento e seus limites - tensão que, segundo ele, fertilizaria a arte e o pensamento modernos, para além de toda dicotomia entre racionalidade e irracionalismo. Dessa tensão seria exemplo significativo justamente a prática poética de Rimbaud, caracterizada pela recusa do esteticismo, da separação entre forma poética e vida cotidiana, levando-o a antecipar em sua própria poesia a decisão de viver perigosamente um exílio desidealizado, como o do tráfico de armas africano*.

${ }^{12}$ Embora sem poder aprofundar aqui comentários a esse respeito, é bom lembrar que Leminski escreveu para o Pasquim uma coluna intitulada justamente "Indiccionario".
"(Bonvicino, Régis. "Nota à $2^{\mathrm{a}}$ edição". Ob. cit.:10).

"(: 10).

" (Cf. Jay, Martín. "El mo. dernismo y el abandono de la forma". Em: Campos de fuerza. Entre la historia intelectual y la critica cultu. ral. Buenos Aires: Paidos, 2003: 279-80). 
"(Rancière, Jacques. Políticas da escrita. Ob. cit.: 166).

" (Leminski, Paulo \& Bon vicino, Régis. Envie meu dicionário. Cartas e alguma crítica. Ob. cit.:100).
Desse duplo valor é signo seu interesse pelo dicionário, pelas palavras que freqüentam o poema e o mais impuro comércio. Como escreve Jacques Rancière, "ele não acredita que seja possível destacar as qualidades das coisas e purificar as palavras da tribo. Para ele, as coisas e a linguagem do comércio não se deixam separar das coisas e da linguagem da poesia"*. Por isso mesmo, Rimbaud não poderia ser considerado um poeta de vanguarda, a não ser, talvez, de uma vanguarda vulgar, como propunha Leminski, ciente da impossibilidade ou inutilidade de uma linguagem poética completamente pura. Evidentemente, em um como em outro, exílio e morte precoce são sintomas da dificuldade dessa experiência de comércio híbrido: "A melhor poesia de Rimbaud esteve, porém, em seu gesto final: a recusa do 'sucesso', a escolha do 'fracasso', a derrota da literatura, inimiga da poesia, para que esta triunfasse"*

E em sua própria produção, a tensão entre morte/vida, fracasso/realização, informe/forma, desenvolvida nas cartas e depoimentos que analisamos, é emblematizada no romance-idéia Catatau. Desde a junção entre seu título, da ordem do informe, e sua definição como idéia, ele se mostra híbrido, instável, hesitante, "máquina de linguagem”, excessiva em sua presença de pororoca, compósito de cartesianismo e tropicalismo em atrito, que, no entanto, encena apenas uma espera, um limiar, em suspenso*.

Hibridismos, limiares, iminências... No contexto da vida literária brasileira contemporânea, os espectros de Leminski e seus companheiros de geração - todos póstumos precoces têm sido insistentemente convocados, de diferentes formas: reedições de coletâneas de poemas, biografias, cartas, ensaios ${ }^{13}$. Se compreendermos que, através deles, evocam-se outros espectros, os de Rimbaud e Mallarmé, os dos patriarcas concretos e modernistas, nos daremos conta de que, num período compreendido muitas vezes como fim da história - repetições, citações, esteticismos inócuos -, é a história da poesia moderna em suas origens que é convocada a se originar, outra vez, em possibilidades ainda não cumpridas, plurais, hesitantemente

\footnotetext{
${ }^{13}$ Em relação a Leminski, são bastante representativos do processo de releitura a coletânea de ensaios organizada pelos poetas André Dick e Fabiano Calix to, A linha que nunca termina: Paulo Leminski (Rio de Janeiro: Lamparina, 2004) e, em outro pólo, a interessante tese de doutorado de Fátima Maria de Oliveira, "Correspondência e vida de Paulo Leminski: f(r)icção de (tr)aços ou essa fúria que quer seja lá o que flor”, orientada por Marília Rothier e defendida na PUC-Rio em 2004.
} 
conflitantes. Sem certezas utópicas ou nostálgicas, esses espectros fazem novamente ressoar a pergunta sobre o lugar e o tempo da poesia - confirmando de novo a poesia como pergunta que desloca o sentido de lugar e de tempo.

"Não sei parar na hora/ certa", dizem os versos de Cacaso que tomamos também como epígrafe - e seu erro, sua errância, poesia e vida na corda bamba, parecem querer nos alertar da impossibilidade de resposta à pergunta "Que horas são?"14, símbolo de uma vontade crítica que crê ser possível definir a contemporaneidade de todo presente e de toda palavra, por seu alinhamento ao relógio de uma história unívoca. Esse erro, essa errância ecoam no poema "Volta em aberto", de Leminski: "Ambígua volta/ e torno da ambígua ida/ quantas ambigüidades/ se pode cometer na vida? / Quem parte leva um jeito/ de quem traz a alma torta./ Quem bate mais na porta?/ Quem parte ou quem torna?"

${ }^{14}$ Para uma crítica dos procedimentos de colonização do presente por uma determinada forma de sociologia histórica, são importantes os textos "Para além da história social", de Silviano Santiago, incluído em sua coletânea de ensaios Nas malhas da letra (São Paulo: Companhia das Letras, 1989), e "Figuras do presente", de Marcos Siscar (Em: Instrumento crítico, v. 2. Rondônia, 1999). Ambos têm, não por acaso, o mesmo interlocutor: Roberto Schwarz, autor da coletânea de ensaios Que horas são? (São Paulo: Companhia das Letras, 1987). 
Palavras-chave experiência morte

sobrevida linguagem

\section{Key words \\ experience death \\ survival language \\ Palabras-Ilave experiencia muerte sobrevida lenguaje}

Recebido em 30/11/2005 23/12/2005

\section{Celia Pedrosa}

Professora de Literatura Brasileira e Teoria da Literatura na Universidade Federal Fluminense. Com apoio do CNPq, coordena o grupo de pesquisa "Poesia, Contemporaneidade, Visualidade". Coordena também o projeto de pesquisa "Poéticas contemporâneas: subjetividades e identidades em devir", em convênio da CAPES com a Universidade do Porto. Sobre o tema, além de inúmeros ensaios, tem publicados, como organizadora, os livros Mais poesia hoje (7 Letras), Poesia e contemporaneidade; leituras do presente (Argos) e Poéticas do olhar e outras leituras de poesia (7 Letras), os dois últimos com Maria Lucia Barros Camargo.

\section{Resumo}

Esse ensaio tem como objetivo a leitura articulada de alguns aspectos das cartas, ensaios e biografias escritos por Paulo Leminski. Através dessa leitura, apresenta questões que permitam compreender, em função dos vínculos entre experiência de vida e de linguagem, sua opção por uma atividade intelectual híbrida, que questiona as fronteiras da cultura de seu tempo, bem como, em face dos limites desse tempo, sua idéia de contemporaneidade, assombrada pela sobrevida de personagens de outras épocas e relativizada por sua própria morte precoce.

\section{Abstract}

This study proposes a comprehensive reading of some aspects of Paulo Leminski's letters, essays and biographical writings. A number of points will be raised that will allow, in function of the links between experiences in living and in language, an understanding of Leminski's choice of a hybrid sort of intellectual activity, questioning the boundary lines assumed by the culture of his time, as well as - given the limits of his time - his very concept of contemporariness, haunted by the aterlifeacters from other times and relativized by his own early death.

\section{Resumén}

Ese ensayo tiene como objetivo la lectura articulada de algunos aspectos de las cartas, ensayos y biografías escritas por Paulo Leminski. Desde esa lectura, se propone presentar algunas cuestiones que permitan comprender, en función de los vínculos entre la experiencia vivida de vida y de lenguaje, su opción por una actividad intelectual híbrida, que cuestiona las fronteras de la cultura de su tiempo, así como, frente a los límites de ese tiempo, su propia idea de contemporaneidad, asombrada por la sobrevida de personajes de otras épocas y relativizada por su muerte precoz. 